\title{
ANALISIS MOTIVASI BELAJAR SISWA SMP KELAS VIII MELALUI MEDIA PEMBELAJARAN GEOGEBRA
}

\author{
Hamka Abdul Hakim', Koswara², Wahyu Setiawan ${ }^{3}$ \\ 1,2,3 IKIP Siliwangi Bandung \\ 1'hamkaabdulhakim123@gmail.com.2koswara927@gmail.com.3kakwahyu3@gmail.com
}

\begin{abstract}
This study aims to analyze the learning motivation of class VIII SMP students through Geogebra learning media. The method of this research is quasi research. The research population was 120 class VIII students of SMP Negeri 3 Naringgul. The sample or subject of this study were 28 students. Data collection techniques are non-test or questionnaire. The data collection tool is a questionnaire sheet. The data analysis technique uses descriptive techniques. In general, the results of the research on positive agreement with a high percentage where the Very Agree (SS) response produces an average of $27.2 \%$ with the criteria of almost half. Whereas in the Agree (S) and Disagree (TS) responses each with an average of $68.2 \%$ with criteria mostly and $6.6 \%$ on the criteria for a small part, meaning that it can be concluded that geogebra learning media succeeded in increasing student learning motivation seen from the percentage of Strongly Agree (SS) and Agree (S) responses that are more dominant than the percentage of the Disagree (TS) and Strongly Disagree (STS) responses.
\end{abstract}

Keywords: Learning motivation, Geogebra Learning Media

\begin{abstract}
Abstrak
Penelitian ini bertujuan untuk menganalisis motivasi belajar siswa kelas VIII SMP melalui media pembelajaran Geogebra. Metode penelitian ini adalah penelitian kuasi. Populasi penelitian 120 siswa kelas VIII SMPN 3 Naringgul. Sampel atau subjek penelitian ini adalah 28 siswa. Teknik pengumpulan data adalah non tes atau angket. Alat pengumpulan data adalah lembar angket. Teknik analisis data menggunakan teknik deskriptif. Secara umum, hasil penelitian pada persetujuan positif dengan persentase yang tinggi dimana pada respon Sangat Setuju (SS) menghasilkan rata - rata sebesar 27,2 \% dengan kriteria hampir setengahnya. Sedangkan pada respon Setuju (S) serta Tidak Setuju (TS) masing - masing dengan rata - rata 68,2 \% dengan kriteria sebagian besar dan 6,6 \% pada kriteria sebagian kecil, artinya dapat ditarik kesimpulan bahwa media pembelajaran geogebra berhasil memberikan dampak positif terhadap peningkatkan motivasi belajar dilihat dari persentase respon Sangat Setuju (SS) dan Setuju (S) yang lebih dominan daripada persentase respon Tidak Setuju (TS) serta Sangat Tidak Setuju (STS).
\end{abstract}

Kata Kunci: Motivasi belajar, Media Pembelajaran Geogebra

How to cite: Hakim, H A, Koswara., \& Setiawan, W. (2019). Analisis motivasi belajar siswa SMP kelas VIII melalui media pembelajaran Geogebra. JPMI - Jurnal Pembelajaran Matematika Inovatif, 2 (5), 237-244.

\section{PENDAHULUAN}

Keberhasilan suatu proses pembelajaran dapat diketahui dan diukur secara umum dari penguasaan siswa pada materi yang telah diajarkan. Lebih lengkap lagi ketika siswa betul betul memahami pentingnya motivasi belajar, supaya pembelajaran yang dilakukan lebih bermakna. pentingnya motivasi yang kuat untuk menunjang berhasil tidaknya seorang siswa 
dalam usaha belajarnya. Dengan terus menerus diberikan suntikan motivasi, maka dampak positif akan dirasakan oleh siswa secara nyata selama siswa tersebut menjalani proses belajar. Sedikit demi sedikit siswa kurang motivasi, maka sedikit demi sedikit pula siswa diberikan motivasi dengan kadar yang disesuaikan. Kemudian hal lain adalah harus kreatifnya guru dalam memilih media pembelajaran sebagai pendukung proses pembelajaran agar terdapat peningkatan motivasi belajar.

Menurut Doyan, Gunada, Susilawati, \& Adriani (2015) siswa yang memiliki motivasi belajar tinggi akan memberikan hasil belajar yang lebih baik dibanding dengan siswa yang memiliki motivasi belajar rendah. Hal itu menunjukkan keterkaitan antara hasil dan motivasi belajar. Telah terjadi kemajuan kearah yang lebih positif, adanya pengaruh dari motivasi belajar. Baik pada pendidikan tingkat bawah atau tingkat tinggi. Dimana motivasi memiliki kedudukan yang diperhitungkan untuk menjadi modal awal dalam melakukan proses pembelajaran. Motivasi harus mempunyai tempat khusus diawal, sedang dan setelah pembelajaran selesai. Selaras dengan pendapat sebelumnya oleh Mediawati (2010) Motivasi belajar mahasiswa dan kompetensi dosen memiliki pengaruh positif dan signifikan baik secara parsial maupun simultan terhadap prestasi belajar mahasiswa.

Adapun kondisi dilapangan memang perlu kita akui bersama, dimana motivasi adalah salah satu faktor pendukung keberhasilan belajar. Adanya dorongan dari diri sendiri perlu ditumbuhkan secara intensif. Agar pembelajaran lebih terarah menjadi pembelajaran yang maksimal. Motivasi yang terdapat dilapangan memang miris adanya, terutama pada mata pelajaran matematika. Siswa diharapkan dapat terus termotivasi untuk belajar selama berada dilingkungan sekolah. Ketika tidak ada motivasi, maka yang terjadi bukan fokus pada pembelajaran yang dilakukan dikelas akan tetapi pada jam pulang. Kerepotan yang akan dialami oleh guru ketika harus menahan siswa tetap ikut pada proses pembelajaran. Hal ini senada dengan kondisi lapangan yang disampaikan oleh Ricardo \& Meilani (2017) berdasarkan hasil wawancara penulis dengan kepala sekolah dan guru mata pelajaran tersebut, diperoleh informasi bahwa disekolah mereka, minat dan motivasi belajar siswa masih cukup rendah. Hasil olah data empiris pada jumlah siswa yang absen dan data rekapitulasi jumlah siswa dengan nilai yang masih rendah pun mendukung apa yang mereka kemukakan. Sebagai contoh dampak negatif adalah pada kehadiran siswa, dimana siswa enggan untuk mengikuti pembelajaran.

Dari sekian banyak materi matematika, salah satunya adalah materi lingkaran. Materi ini melibatkan gambar yang harus ditampilkan untuk membantu siswa dalam membayangkan gambar atau bentuk yang tengah dibahas. Dimana secara umum lingkaran adalah kurva tertutup sederhana yang merupakan tempat kedudukan titik- titik yang berjarak sama terhadap suatu titik tertentu. Jarak yang sama tersebut disebut jari-jari lingkaran dan titik tertentu disebut pusat lingkaran. Nur, Harahap, Badruzzaman, \& Darmawan (2017) menggambarkan serta menganalisis geometri dalam Matematika mudah dilakukan dengan menggunakan media aplikasi Geogebra. Artinya Geogebra dapat membantu siswa dalam membayangkan atau menggambarkan bentuk dari lingkaran yang akan jadi bahan pembahasan. Pada Khadijah, Maya, \& Setiawan (2018) memberikan kesimpulan bahwa pada indikator Menyatakan atau menjelaskan model matematika bentuk gambar ke dalam bahasa biasa 68,18\% (Baik), dimana dengan hasil tersebut menunjukkan bentuk atau konsep matematik lebih mudah dipahami dengan baik apabila melibatkan proses bimbingan dengan menggunakan benda atau bentuk tertentu yang disajikan secara nyata. 


\section{METODE}

Metode dalam penelitian ini adalah eksperimen kuasi. Penelitian ini menggunakan teknik deskriptif kuantitatif persentase yaitu penelitian yang menghasilkan data deskriptif melalui angka-angka atau lebih jelasnya adalah persentase tiap butir soal angket yang diberikan. Penggunaan metode deskriptif pada penelitian ini adalah analisis atau gambaran dari keadaan pada saat pembelajaran matematik menggunakan media pembelajaran geogebra. Analisis data yang berhubungan dengan pelaksanaan pembelajaran dengan media pembelajaran geogebra kemudian melakukan perhitungan rata-rata dari setiap indikator. Adapun untuk dijadikan sebagai sumber kesimpulan diambil dari rata-rata secara keseluruhan. Untuk menghitung ratarata digunakan rumus yang dimuat pada Arikunto (2010) yaitu sebagai berikut :

$\bar{x}=\frac{\sum x}{n}$

Keterangan :

$\bar{x}=$ Rata-rata (mean)

$\sum x=$ Jumlah seluruh skor

$\mathrm{n}=$ Banyaknya subjek

Sedangkan analisis data yang berhubungan dengan motivasi belajar yaitu dengan perhitungan presentase. Adapun menghitung presentase motivasi belajar siswa yaitu dengan menggunakan rumus dari Sudijono (2008) seperti berikut :

$P=\frac{f}{N} x 100 \%$

Keterangan :

$\mathrm{P}=$ angka presentase

$\mathrm{f}=$ frekuensi yang muncul

$\mathrm{N}=$ jumlah frekuensi atau banyaknya individu

Untuk menentukan kategori dipergunakan tolak ukur menurut Ali \& Asrori (2005) sebagai berikut :

\begin{tabular}{ll}
\hline $75,01 \%-100 \%$ & Sangat baik \\
$50,01 \%-75,00 \%$ & Baik \\
$25,01 \%-50,00 \%$ & Cukup Baik \\
$0,01 \%-25,00 \%$ & Kurang baik
\end{tabular}

Teknik pengumpulan data adalah non tes atau angket. Alat pengumpulan data adalah lembar angket. Teknik analisis data menggunakan teknik deskriptif. Populasi penelitian 120 siswa kelas VIII SMPN 3 Naringgul. Sampel atau subjek penelitian ini adalah 28 siswa kelas VIII pada tahun pelajaran 2018/2019 beralamat di Jalan Raya Naringgul Cigaru Desa Wangunjaya Kecamatan Naringgul Kabupaten Cianjur. Penelitian ini mendeskripsikan respon siswa terhadap aplikasi geogebra yang telah direkam melalui bagaimana siswa menjabarkan pengalaman belajarnya melalui angket yang diberikan terkait motivasi belajar, kemudian diolah sesuai dengan jumlah setiap butir angket. Hasil pengolahan tersebut kemudian dipaparkan dengan bentuk persentase sehingga lebih mudah dalam memahami makna dari informasi yang hendak disampaikan. Hasil olahan data dengan persentase ini hanya sampai pada tahap pendeskripsian, belum sampai pada tahap menggeneralisasikan. Dengan kata lain, persentase deskriptif adalah persentase yang mempunyai arah mengorganisasi serta menganalisa data angka. Berupa angka persentase tiap butir angket, sehingga memberikan gambaran secara teratur, ringkas serta jelas, sehingga dapat diambil pengertian atau makna tertentu atas penerapan media pembelajaran. 


\section{HASIL DAN PEMBAHASAN}

\section{Hasil}

Hasil - Langkah awal dalam penelitian ini adalah memberikan soal angket, angket itu sendiri adalah tes yang digunakan untuk mengetahui motivasi siswa setelah dalam pembelajarannya dimuat aplikasi geogebra. Sehingga berdasarkan acuan tersebut dapat terlihat sejauh mana keberhasilan ketermotivasian siswa dengan media pembelajaran geogebra. Hasil dari analisis ini berupa beberapa persentase angket motivasi belajar yang terdiri dari 10 indikator. Hasil persentase ini dapat dilihat dalam Tabel berikut :

Tabel 1. Persentase Angket Motivasi Belajar

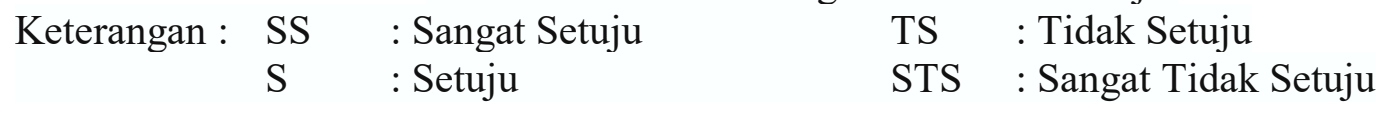

\begin{tabular}{llcccc}
\hline \multirow{2}{*}{ No. } & \multicolumn{1}{c}{ Indikator } & \multicolumn{4}{c}{ Respons } \\
\cline { 3 - 6 } & & SS & S & TS & STS \\
\hline 1. & Adanya Hasrat dan Keinginan untuk berhasil & 25.0 & 75.0 & - & - \\
2. & Adanya dorongan dan kebutuhan dalam belajar & 25.0 & 71.4 & 3.6 & - \\
3. & Adanya harapan dan cita - cita masa depan & 17.9 & 78.6 & 3.5 & - \\
4. & Adanya penghargaan dalam belajar & 28.6 & 71.4 & - & - \\
5. & Adanya kegiatan yang menarik dalam belajar & 32.2 & 57.1 & 10.7 & - \\
6. & Percaya diri dalam menggunakan matematika & 32.1 & 67.9 & - & - \\
7. & Fleksibel dalam melakukan kerja matematika & 39.3 & 53.6 & 7.1 & - \\
8. & Kerelaan meninggalkan kewajiban atau tugas lain & 17.9 & 75.0 & 7.1 & - \\
9. & Ketekunan dalam mengerjakan matematika & 35.7 & 60.7 & 3.6 & - \\
10. & Dapat mempertahankan pendapat & 17.9 & 71.4 & 10.7 & - \\
\hline
\end{tabular}

\section{Pembahasan}

Hasil dari tes diagnostik untuk 28 orang siswa yang menjawab Sangat Setuju (SS), Setuju (S), Tidak Setuju (TS), Sangat Tidak Setuju (STS) pada setiap indikator dijabarkan dalam bentuk diagram sebagai berikut :

1. Adanya hasrat dan keinginan untuk berhasil

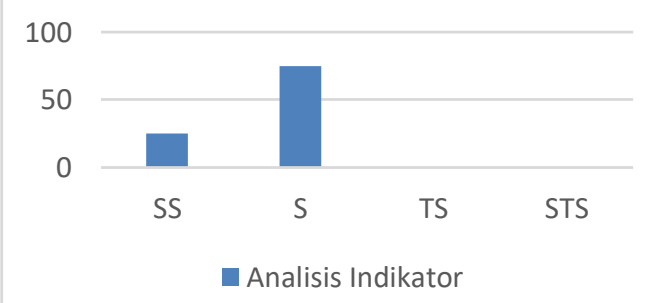

Bisa kita lihat dari diagram diatas, dimana 75\% siswa menyatakan setuju (S) untuk indikator adanya hasrat dan keinginan untuk berhasil. Sedangkan ada $25 \%$ sisanya menyatakan sangat setuju (SS) berada pada kriteria Rendah, artinya ada 7 orang siswa. Adapun untuk respon tidak setuju (TS) dan sangat tidak setuju (STS) menghasilkan respon yang nihil atau $0 \%$. Hal ini menunjukkan bahwa dari total siswa 28 orang yang mengikuti pembelajaran atau bisa dikatakan 21 orang siswa merasakan dampak positif setelah diterapkannya media 
pembelajaran berupa geogebra. Selama pembelajaran siswa disuguhkan untuk mengamati materi ajar yang dikemas secara menarik. Sehingga hasrat siswa dalam belajar semakin terangsang.

2. Adanya dorongan dan kebutuhan dalam belajar

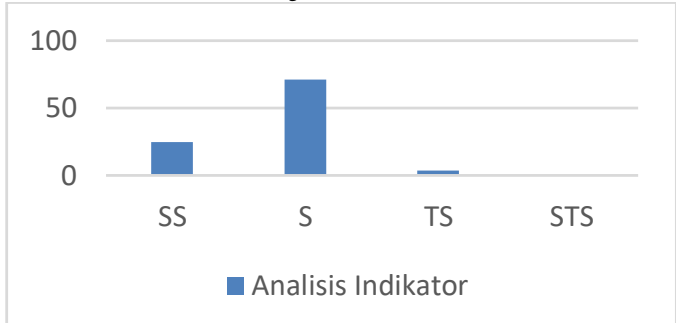

Berdasarkan analisis deskriptif untuk indikator adanya dorongan dan kebutuhan dalam belajar, menunjukkan $25 \%$ pada kriteria Rendah atau 7 orang siswa sangat setuju (SS) dengan perkembangan positif selama pembelajaran berlangsung dengan menggunakan media pembelajaran geogebra. Dimana siswa secara tidak sadar mengikuti pembelajaran tanpa adanya pemaksaan dari pihak manapun. Bisa dilihat dari $71,4 \%$ pada kriteria Tinggi siswa menyatakan setuju (S) dengan penerapan geogebra, kurang lebih 19,99 orang siswa atau dibulatkan menjadi 20 orang siswa. Sedangkan untuk kategori tidak setuju (TS) menghasilkan persentase 3,6 \% dengan kriteria Sangat Rendah atau sekitar 1 orang siswa, dan untuk respon sangat tidak setuju (STS) mendapatkan persentase nihil yaitu $0 \%$.

3. Adanya harapan dan cita - cita masa depan

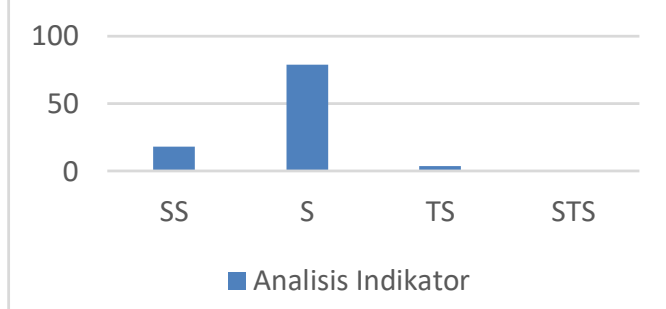

Berdasarkan analisis deskriptif untuk indikator adanya harapan dan cita-cita masa depan, menunjukkan $17,9 \%$ pada kriteria Sangat Rendah atau 5 orang siswa sangat setuju (SS) dengan perkembangan positif selama pembelajaran berlangsung dengan menggunakan media pembelajaran geogebra. Kemudian ada 78,6 \% siswa menyatakan setuju (S) pada kriteria Sangat Tinggi dengan penerapan geogebra, kurang lebih 22 orang siswa. Sedangkan untuk kategori tidak setuju (TS) menghasilkan persentase 3,6 \% pada kriteria Sangat Rendah atau sekitar 1 orang siswa, dan untuk respon sangat tidak setuju (STS) mendapatkan persentase nihil yaitu $0 \%$.

4. Adanya penghargaan dalam belajar

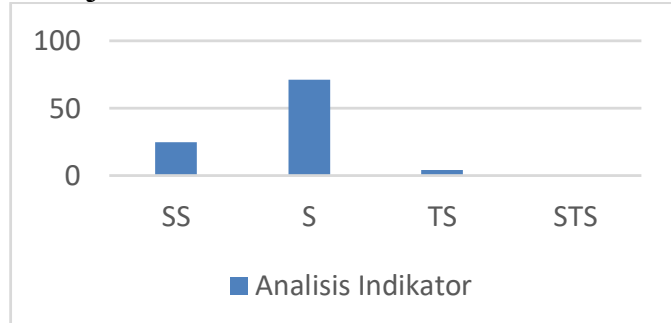

Berdasarkan analisis deskriptif untuk indikator adanya penghargaan dalam belajar, menunjukkan $28,6 \%$ pada kriteria Rendah atau 8 orang siswa sangat setuju (SS) dengan perkembangan positif selama pembelajaran berlangsung dengan menggunakan media 
pembelajaran geogebra. Kemudian ada 71,4 \% pada kriteria Tinggi siswa menyatakan setuju (S) dengan penerapan geogebra, kurang lebih ada 20 orang siswa. Sedangkan untuk respon tidak setuju (TS) dan sangat tidak setuju (STS) sama - sama menghasilkan persentase yang nihil yaitu $0 \%$.

5. Adanya kegiatan yang menarik dalam belajar

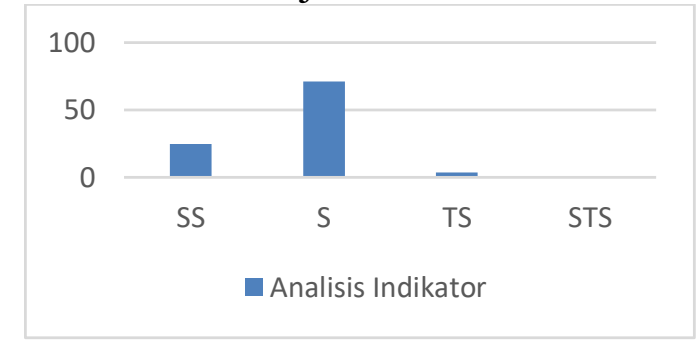

Berdasarkan analisis deskriptif untuk indikator adanya kegiatan yang menarik dalam belajar, menunjukkan 32,1 \% pada kriteria Rendah atau 9 orang siswa sangat setuju (SS) dengan perkembangan positif selama pembelajaran berlangsung dengan menggunakan media pembelajaran geogebra. Kemudian ada 57,1 \% dengan kriteria Tinggi siswa menyatakan setuju (S) dengan penerapan geogebra, kurang lebih 16 orang siswa. Untuk respon tidak setuju (TS) menghasilkan persentase sebesar 10,7\% pada kriteria Sangat Rendah atau 3 orang siswa, sedangkan untuk respon sangat tidak setuju (STS) menghasilkan persentase yang nihil atau $0 \%$.

6. Percaya diri dalam menggunakan matematika

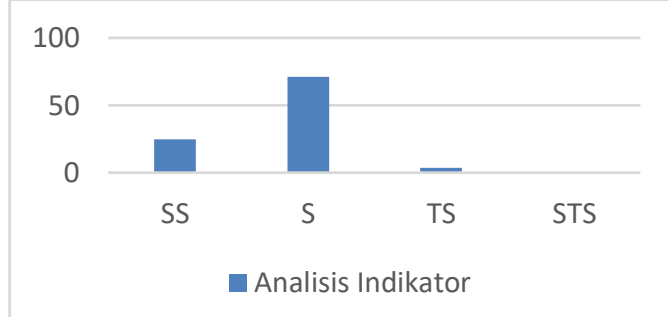

Berdasarkan analisis deskriptif untuk indikator percaya diri dalam menggunakan matematika, menunjukkan persentase $32,1 \%$ pada kriteria Rendah atau 9 orang siswa sangat setuju (SS) dengan perkembangan positif selama pembelajaran dengan menggunakan media pembelajaran geogebra. Kemudian ada $67,9 \%$ pada kriteria Tinggi menyatakan setuju (S) dengan penerapan geogebra, atau kurang lebih ada 19 orang siswa. Sedangkan untuk respon tidak setuju (TS) dan sangat tidak setuju (STS) sama - sama menghasilkan persentase yang nihil yaitu $0 \%$.

Rata - rata hasil analisis diatas mengarah kepada hasil yang positif dan berhasil mengupayakan siswa dalam kegiatan belajar yang mandiri, nyaman, dan antusias serta mampu dengan baik saling berinteraksi dengan media pembelajaran yang disajikan. Siswa lebih mampu mengakomodir pemahaman abstrak menjadi pemahaman yang lebih konkret. Dengan rangsangan media pembelajaran geogebra. Hal ini selaras dengan Jasija, Fitriana, \& Aripin (2018) yang menyatakan bahwa siswa yang mengikuti pembelajaran RME terlihat merasa senang, nyaman, antusias dalam belajar, lebih baik dan dapat menyelesaikan masalah kontekstual dengan benar dan tepat. Dimana pembelajaran RME juga tidak lepas dari media pembelajaran dan masalah yang berkaitan dengan kejadian sehari-hari. 


\section{KESIMPULAN}

Pembelajaran matematika terutama pada materi lingkaran dengan penggunaan media pembelajaran geogebra berpengaruh terhadap motivasi belajar siswa SMP Kelas VIII. Siswa lebih terfokus lagi untuk memahami konsep atau materi yang hendak disampaikan oleh guru. Dengan adanya bantuan dari media pembelajaran geogebra, interaksi yang diharapkan dapat berjalan dengan lancar. Peran serta antara guru dan siswa dapat berjalan dengan baik. Dimana siswa semakin terangsang untuk memulai pembelajaran karena adanya dorongan dari dirinya sendiri yang berasal dari media. Dapat dibuktikan dengan persentase yang tinggi dimana pada respon Sangat Setuju (SS) menghasilkan rata - rata sebesar 27,2 \%. Untuk respon Setuju (S) dan Tidak Setuju (TS) masing - masing dengan rata - rata 68,2 \% dan 6,6 \%. Sedangkan untuk respon Sangat Tidak Setuju (STS) menghasilkan persentase yang nihil atau $0 \%$.

\section{DAFTAR PUSTAKA}

Ali, M., \& Asrori, M. (2005). Psikologi Remaja Perkembangan Peserta Didik. PT Bumi Aksara.

Arikunto, S. (2010). Prosedur Penelitian Suatu Pendekatan Praktik. Jakarta: PT. Rineka Cipta.

Doyan, A., Gunada, W., Susilawati, \& Adriani, I. A. D. (2015). Perbedaan Pengaruh Model Pembelajaran Kooperatif Tipe STAD dan Tipe Jigsaw terhadap Hasil Belajar Fisika ditinjau dari Motivasi Belajar Siswa. Jurnal Penelitian Pendidikan IPA (JPPIPA), 1(1), $1-13$.

Jasija, K., Fitriana, F. A., \& Aripin, U. (2018). Pendekatan Realistic Mathematics Education Untuk Meningkatkan Kemampuan Generalisasi Matematis Siswa. Jurnal Penelitian Dan Pembelajaran Matematika, 10(2), 915-922. https://doi.org/10.30870/jppm.v10i2.2043

Khadijah, I. N. A., Maya, R., \& Setiawan, W. (2018). Analisis kemampuan komunikasi matematis siswa smp pada materi statistika. Jurnal Pembelajaran Matematika Inovatif, 1(6), 1095-1104.

Mediawati, E. (2010). Pengaruh Motivasi Belajar Mahasiswa dan Kompetensi Dosen terhadap Prestasi Belajar. Jurnal Pendidikan Ekonomi Dinamika Pendidikan, V(2), 134146.

Nur, I. L., Harahap, E., Badruzzaman, F. H., \& Darmawan, D. (2017). Pembelajaran Matematika Geometri Secara Realistis Dengan GeoGebra. Jurnal Matematika, 16(2), 16.

Ricardo, \& Meilani, R. I. (2017). Impak Minat dan Motivasi Belajar terhadap Hasil Belajar Siswa. Jurnal Pendidikan Manajemen Perkantoran, 1(1), 79-92.

Sudijono, A. (2008). Pengantar Evaluasi Pendidikan. Jakarta: Raja Grafindo Persada. 
244 Hakim, Koswara \& Setiawan, Analisis Motivasi Belajar Siswa SMP Kelas VIII melalui ...... 